IDEAs IN Ectlagy AND Evalutian 13: 59-60, 2020

doi:10.24908/iee.2020.13.5.c

(C) 2020 The Author

Received 10 May 2020; Accepted 12 Nov 2020

Commentary

\title{
A uniquely fire creature, a uniquely fire planet
}

\section{Stephen J. Pyne}

Stephen J. Pyne (STEPHEN.PYNE@asu.edu), School of Life Sciences, Arizona State University, Box 873301, Tempe, AZ, USA 85287

Lamont and He (2020) offer an argument-in terms of genre, perhaps an appeal-to colleagues in ecology and evolutionary biology to consider fire as a disturbance of fundamental relevance to their discipline. They make their case by a systematic review of questions that, by consensus, those colleagues regard as significant to the topic.

I'm not among those colleagues. I'm a fire guy and historian, who has written textbooks on fire and fire histories for at least parts of all the vegetated continents. From that experience, here I offer three observations that I hope will encourage further consideration of the main argument.

\section{(1) We can make a bolder claim.}

Fire is not simply a 'disturbance' that impinges upon the living world; it is a creation of the living world. Life supplies the oxygen, life creates and arranges the fuel, and, in the hands of humans, life furnishes the vast majority of ignitions. As soon as plants colonized the continents, they burned and have burned ever since. Even the chemistry of fire is biochemistry: it takes apart what photosynthesis puts together. When it occurs in cells, we call it respiration; when in the wide world, fire. It is a biological disturbance.

All this makes fire basic to Earth and terrestrial life. It should be one of the great ontological categories of life science. In many places it is no more a disturbance than is rain. That Lamont and He (and others) have to argue as they do is astonishing-or so it seems to someone who has studied fire but not as a credentialed biologist. Is fire missing from ecology and evolution? In truth, fire is missing from biology overall. Where is it in basic biology texts?

\section{(2) Why/how did fire get misplaced?}

The explanation lies not in nature but in the traditions of those investigating nature. Fire as a category disappeared in the late 18th century; even today it has no academic department (as earth, water, and air do); it is among the disciplinary homeless. Its essence - its capacity to integrate its surroundingscan work against it when the thrust of modern inquiry is reductionism.

Fire as a subject should have co-evolved with the life sciences as fire, the phenomenon, did with life. It was there for all to see, but no one in biology was trained to see it. It didn't happen. Instead, landscape fire settled, by accident, and as an uninvited house guest, in forestry, which didn't want it and then reluctantly studied it in order to control, and if possible, evict it. No wonder fire now seems everywhere and nowhere. Its invisibility and vagrancy was a byproduct of how biology emerged as a discipline. Now researchers face a daunting intellectual retrofit.

\section{(3) Where are the people?}

Humans are the keystone species for fire on the planet. The Anthropocene is powered by humanity's species monopoly over fire, particularly its transition from burning living biomass to burning fossil varieties. Almost every aspect of fire's presence is affected by humanity's fiddling; thanks to people, even climate history is now a subnarrative of fire history. The human presence-the human fire presence - is so powerful an ecological and evolutionary force that it is now impossible to talk coherently about fire on Earth today without including people. And vice versa: it is implausible to talk about the 
human presence without reference to our firepower. Manipulating fire is our unique ecological signature.

One reason for the exclusion of fire from ecological science is that, until recently, researchers didn't incorporate human actions. With the general acknowledgement of an Anthropocene, both topics, people and fire, have become unavoidable. In fact, I would argue that the sum of humanity's fire practices is creating the fire equivalent of an ice age, with immense disruptions in biogeography, changes in sealevel, and mass extinctions, not to mention the expulsion of planetary ice. People are at the nuclear core of these reconfigurations. Their Archimedean lever is a firestick.

For those who have worked in fire for years, or decades, the argument presented by Lamont and $\mathrm{He}$ has long seemed self-evident. But clearly it is not intrinsically apparent to scientists outside what, until recently, has been a fairly selective tribe. Getting the word out to people who have missed all the memos being sent by nature is a good idea.

\section{References}

Bowman, D.M.J.S., Balch, J., Artaxo, P., Bond, W.J., Cochrane, M.A., D’Antonio, C.M., et al. 2011. The human dimension of fire regimes on Earth. Journal of Biogeography 38(12): 2223-2236. CrossRef

Lamont, B.B., and T. He. 2020. The third dimension: How fire-related research can advance ecology and evolutionary biology. Ideas in Ecology and Evolution 13: 25-58. CrossRef

Pyne, S.J. 2019. Fire: A Brief History, $2^{\text {nd }}$ edition. University of Washington Press.

Pyne, S.J. 2019. The Planet is Burning. Aeon (19 Nov 2019). Available at: https://aeon.co/essays/theplanet-is-burning-around-us-is-it-time-to-declarethe-pyrocene

Scott, A. Bowman, D.M.J.S., Bond, W.J., Pyne, S.J., and M.E. Alexander. 2014. Fire on Earth: An Introduction. Wiley Blackwell. 